\title{
Comparative Study of Various Treatments For Dairy Industry Wastewater
}

\author{
Mrs. Bharati S. Shete, Dr. N. P. Shinkar \\ 1 Dr. Sau. Kamaltai Gawai Institute of Engineering \& Technology, Darapur, Amravati, Maharashtra, India \\ 2 Department of Civil Engineering, Government Polytechnic, Amravati, Maharashtra, India
}

\begin{abstract}
Dairy industries have shown tremendous growth in size and number in most countries of the world. These industries discharge wastewater which is characterized by high chemical oxygen demand, biological oxygen demand, nutrients, and organic and inorganic contents. Such wastewaters, if discharged without proper treatment, severely pollute receiving water bodies. In this article, the various recent advancements in the treatment of dairy wastewater have been discussed and stress is given on the lowest cost of the best possible treatment.
\end{abstract}

Keywords:- Aerobic treatment, anaerobic treatment, Anaerobic fixed bed reactor, Dairy industry, Wastewater characteristics

\section{INTRODUCTION}

The dairy industry wastewaters are primarily generated from the cleaning and washing operations in the milk processing plants. It is estimated that about $2 \%$ of the total milk processed is wasted into drains. Dairy wastewaters are characterized by high biological-oxygen demand (BOD) and chemical oxygen demand (COD) concentrations, and generally contain fats, nutrients, lactose, as well as detergents and sanitizing agents. Dairy effluents decompose rapidly and deplete the dissolved oxygen level of the receiving streams immediately resulting in anaerobic conditions and release of strong foul odours due to nuisance conditions. The receiving water becomes breeding place for flies and mosquitoes carrying malaria and other dangerous diseases like dengue fever, yellow fever, chicken guniya. It is also reported that higher concentration of dairy wastes are toxic to certain varieties of fish and algae. The casein precipitation from waste which decomposes further into a highly odorous black sludge at certain dilutions the dairy waste is found to be toxic to fish also. Dairy effluent contains soluble organics, suspended, solids, trace organics. They decrease do, promote release of gases, cause taste and odour, impart colour or turbidity, promote eutrophication.

Due to the high pollution load of dairy wastewater, the milk-processing industries discharging untreated/partially treated wastewater cause serious environmental problems. Moreover, the Indian government has imposed very strict rules and regulations for the effluent discharge to protect the environment (Table 1). Thus, appropriate treatment methods are required so as to meet the effluent discharge standards.

Dairy wastewaters are generally treated using biological methods such as activated sludge process, aerated lagoons, trickling filters, sequencing batch reactor (SBR), anaerobic sludge blanket (UASB) reactor, anaerobic filters, etc. Oftentimes the post-treatment of dairy wastewater is also done using the physico-chemical treatment methods consisting of coagulation/flocculation by various inorganic and organic natural coagulants, and membrane processes like nanofiltration (NF) and/or reverse osmosis (RO). Membrane processes produce purified water without milk proteins and lactose and which could be recycled. At the same time the recovered proteins and lactose can be used for non-human consumption[1].

Table 1:- Minimal standards for discharge of effluents from the dairy industry

\begin{tabular}{|l|c|c|}
\hline \multirow{2}{*}{ PARAMETER } & \multicolumn{2}{c|}{ MAXIMUM VALUE (mg/l) } \\
\cline { 2 - 3 } & WORLD BANK REPORT & CPCB, INDIA \\
\hline $\mathrm{pH}$ & $6-9$ & $6.5-8.5$ \\
\hline $\mathrm{BOD}_{5}$ & 50 & 100 (based on BOD $_{5}$ ) \\
\hline $\mathrm{COD}$ & 250 & - \\
\hline Total Suspended Solids & 50 & 150 \\
\hline Oil \& Grease & 10 & - \\
\hline Total Nitrogen & 10 & - \\
\hline Total Phosphoruus & 2 & - \\
\hline Temperature Increase & $<=3^{0} \mathrm{C}$ & - \\
\hline Coliform Bacteria & 400 Most Probable Number / $100 \mathrm{ml}$ & \\
\hline
\end{tabular}




\section{WASTEWATER GENERATION AND CHARACTERISTICS}

Dairy industries are involved in the manufacturing of various types of milk products such as fluid milk, butter, cheese, yogurt, condensed milk, flavored milk, milk powder, ice cream, etc. Typical by-products obtained include buttermilk, whey, and their derivatives. A chain of operations involving receiving and storing of raw materials, processing of raw materials into finished products, packaging and storing of finished products, and a group of other ancillary operations (e.g., heat transfer and cleaning) are examples of some of the great variety of operations performed in the dairy industries. The initial operations such as homogenization, standardization, clarification, separation, and pasteurization are common to most plants and products. Clarification (removal of suspended matter) and separation (removal of cream for milk standardization to desired butterfat content), generally, are accomplished by specially designed large centrifuges. Drying, condensing, etc. are also used in dairy industries for the production of various products. In the dairy industry, some amount of wastewater gets produced during starting, equilibrating, stopping, and rinsing of the processing units (flushing water, first rinse water, etc.). However, a majority of wastewater gets produced during cleaning operations, especially between product changes when different types of products are produced in a specific production unit and clean-up operations (Fig. 1). Figure 1 explains in detail the units involved in milk processing industries and shows the flowchart of Effluent generation from various units

The dairy industry is one of the most polluting of industries, not only in terms of the volume of effluent generated, but also in terms of its characteristics as well. It generates about 0.2-10 liters of effluent per liter of processed milk with an average generation of about 2.5 liters of wastewater per liter of the milk processed. Dairy processing effluents are generated in an intermittent way and the flow rates of these effluents change significantly. Also, the quality and quantity of the product content in the dairy wastewater at a given time changes with the application of another technological cycle in the processing line. Moreover, because the dairy industry produces different products, such as milk, butter, yogurt, ice-cream, and various types of desserts and cheese, the characteristics of these effluents also vary widely both in quantity and quality, depending on the type of system and the methods of operation used.

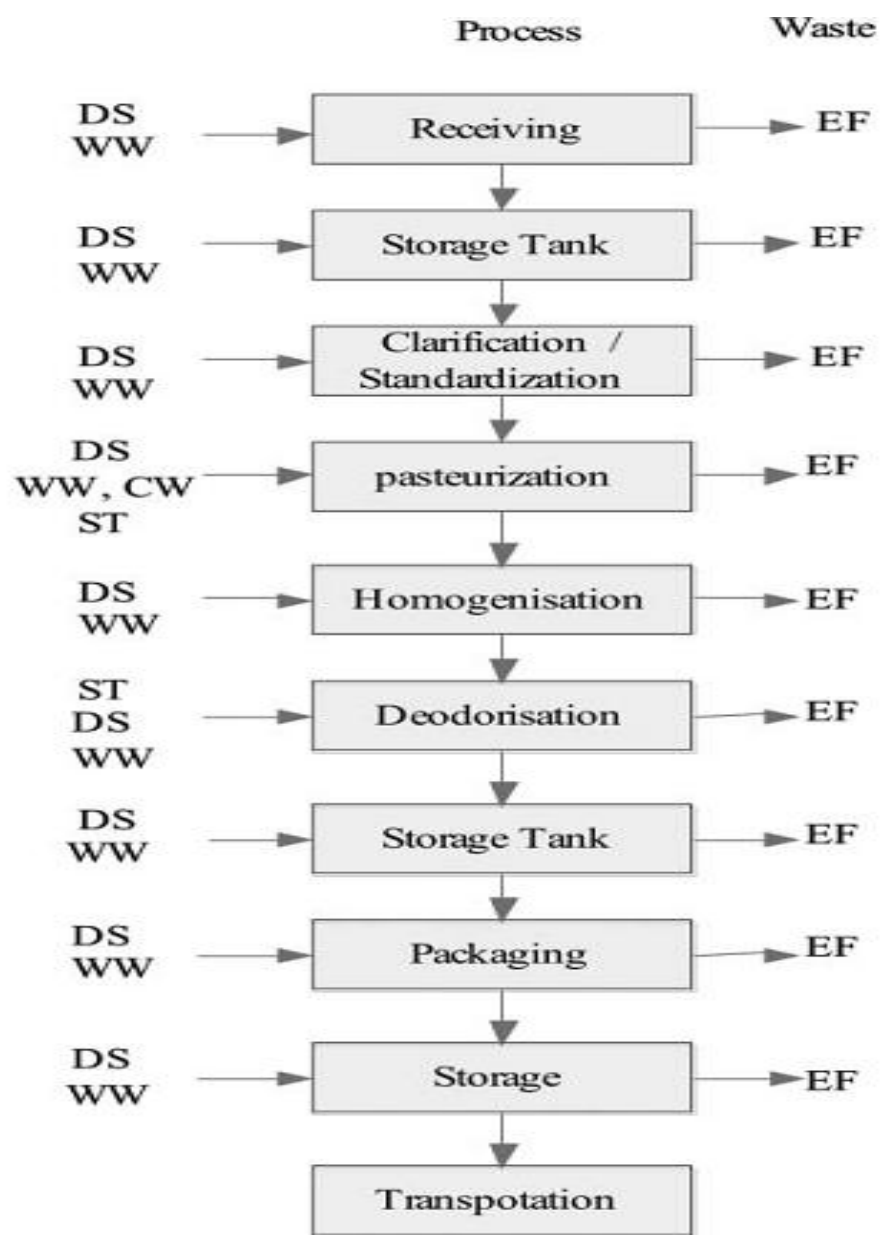

Fig.1: Effluent generation from various units of milk processing. DS-Detergents and Sanitizing Agents, WWWash Water, ST-Steam, CW-Cooling Water. 
Dairy effluent contains soluble organics, suspended solids, trace organics. All these components contribute largely towards their high biological oxygen demand (BODS) and chemical oxygen demand (COD).The characteristics of a dairy effluent contain Temperature, Color, PH (6.5-8.0), DO, BOD, COD, Dissolved solids suspended solids, chlorides sulphate, oil \& grease. The waste water of dairy contains large quantities of milk constituents such as casein, inorganic salts, besides detergents and sanitizers used for washing.[2] It has high sodium content from the use of caustic soda for cleaning. Typical Characteristics of dairy industry wastewaters reported by various authors are given in table 2 .

Table 2:-Characteristics of dairy industry wastewaters (composition in $\mathrm{mg} / \mathrm{l}$, except $\mathrm{pH}$ )

\begin{tabular}{|c|c|c|c|c|c|c|}
\hline WASTE TYPE & COD & BOD & $\mathbf{P}^{\mathrm{H}}$ & TSS & TS & REFERENCES \\
\hline $\begin{array}{l}\text { Milk \& Dairy } \\
\text { Products factory }\end{array}$ & 10251.2 & 4840.6 & 8.34 & 5802.6 & & Oneț Cristian,2010 [3] \\
\hline Dairy effluent & $1900-2700$ & $\begin{array}{l}1200- \\
1800\end{array}$ & $7.2-8.8$ & $500-740$ & $\begin{array}{l}900- \\
1350\end{array}$ & $\begin{array}{l}\text { U. B. Deshannavar, et } \\
\text { al 2012[4] }\end{array}$ \\
\hline Arab Dairy Factory & $\begin{array}{l}3383 \quad \pm \\
1345\end{array}$ & $\begin{array}{l}1941 \pm \\
864\end{array}$ & $\begin{array}{ll}7.9 & \pm \\
1.2 & \end{array}$ & $\begin{array}{ll}831 & \pm \\
392 & \end{array}$ & & $\begin{array}{l}\text { A. Tawfik et. } \\
\text { al,2007[5] }\end{array}$ \\
\hline Dairy waste water & $\begin{array}{l}2,500- \\
3,000\end{array}$ & $\begin{array}{l}1,300- \\
1,600\end{array}$ & $7.2-7.5$ & $\begin{array}{l}72,000- \\
80,000\end{array}$ & $\begin{array}{l}8,000- \\
10,000\end{array}$ & $\begin{array}{l}\text { Javed Iqbal Qazi et. al, } \\
\text { [6] }\end{array}$ \\
\hline $\begin{array}{l}\text { Dairy effluent } \\
\text { (CPCB 1993) }\end{array}$ & $1120-3360$ & $320-1750$ & $5.6-8$ & $28-1900$ & & $\begin{array}{l}\text { Kusum Lata, et. al, } \\
\text { Biogas forum,1999[7] }\end{array}$ \\
\hline Whey & 71526 & 20000 & 4.1 & 22050 & 56782 & $\begin{array}{l}\text { Deshpande D.P. et. al, } \\
\text { 2012[8] }\end{array}$ \\
\hline $\begin{array}{lr}\begin{array}{l}\text { Bhandara } \\
\text { operative }\end{array} & \begin{array}{l}\text { Co- } \\
\text { dairy }\end{array} \\
\text { industry } & \\
\text { wastewater } & \end{array}$ & $\begin{array}{l}1400 \\
2500\end{array}$ & $\begin{array}{ll}800 & \text { to } \\
1000\end{array}$ & $7.1-8.2$ & $\begin{array}{ll}1045 & \text { to } \\
1800\end{array}$ & $\begin{array}{l}1100 \\
\text { to } \\
1600\end{array}$ & $\begin{array}{l}\text { Monali Gotmare* et } \\
\text { al.,2011[9] }\end{array}$ \\
\hline $\begin{array}{l}\text { Cheese } \\
\text { pressed }\end{array}$ & $\begin{array}{l}80,000- \\
90,000\end{array}$ & $\begin{array}{l}120,000- \\
135,000\end{array}$ & 6 & $\begin{array}{l}8000- \\
11000\end{array}$ & & $\begin{array}{l}\text { Rana Kabbout, et } \\
\text { al.,2011 }\end{array}$ \\
\hline $\begin{array}{lr}\text { Aavin } & \text { dairy } \\
\text { industry washwater }\end{array}$ & $2500-3300$ & & $\begin{array}{l}6.4 \\
7.1\end{array}$ & $630-730$ & $\begin{array}{l}1300- \\
1400\end{array}$ & $\begin{array}{l}\text { Sathyamoorthy G.L, et } \\
\text { al.,2012[11] }\end{array}$ \\
\hline $\begin{array}{l}\text { Dairy industry } \\
\text { wastewater }\end{array}$ & 2100 & 1040 & $7-8$ & 1200 & 2500 & A. Arumugam[12] \\
\hline
\end{tabular}

\section{DAIRY WASTEWATER TREATMENT}

Common techniques for treating dairy industry wastewaters include grease traps, oil water separators for separation of floatable solids, equalization of flow, and clarifiers to remove SS. Biological treatment consists of the aerobic and anaerobic process. Sometimes anaerobic treatment followed by aerobic treatment is employed for the reduction of soluble organic matter (BOD) and biological nutrient removal (BNR) is employed for the reduction of nitrogen and phosphorus. Aerobic biological treatment involves microbial degradation and oxidation of waste in the presence of oxygen. Conventional treatment of dairy wastewater by aerobic processes includes processes such as activated sludge, trickling filters, aerated lagoons, or a combination of these[1]. But there are more advanced techniques which will be beneficial to us by providing energy generation and Reuse and energy conservation have become the words of the day and anaerobic processes have emerged with a new potential so we study here some of the anaerobic processes studied by different scientists.

Jai prakash kushwaha et. al.[1] [2011] in his paper, "An Overview of Various Technologies for the Treatment of Dairy Wastewaters" have summarized the aerobic treatment of dairy wastewater by various authors. He claimed that among the various aerobic technologies, sequential batch reactor (SBR) seems to be the most promising technology for treatment of dairy wastewater. It is a fill and draw activated sludge system. In this system, wastewater is added to a single batch reactor, treated to remove undesirable components, and then discharged. Equalization, aeration, and clarification can all be achieved using a single-batch reactor. 
Table 3:- Comparison of advantages and disadvantages of aerobic and anaerobic treatment of dairy industry

\begin{tabular}{|c|c|c|}
\hline \multicolumn{3}{|c|}{ wastewaters } \\
\hline FACTORS & AEROBIC PROCESS & ANAEROBIC PROCESS \\
\hline Reactors & $\begin{array}{l}\text { Aerated lagoons, oxidation ditches, } \\
\text { Stabilization ponds, Trickling filters } \\
\text { and Biological discs }\end{array}$ & $\begin{array}{l}\text { UASB, Anaerobic filter, Upflow packed } \\
\text { bed reactor, CSTR, Down flow fixed- } \\
\text { film reactor, Buoyant Filter Bioreactor, }\end{array}$ \\
\hline Reactor size & $\begin{array}{l}\text { Aerated lagoons, oxidation ditches, } \\
\text { Stabilization ponds, Trickling filters } \\
\text { and Biological discs requires larger } \\
\text { land area but SBR needs } \\
\text { comparatively lower area. }\end{array}$ & Smaller reactor size is required. \\
\hline $\begin{array}{l}\text { Effluent } \\
\text { Quality }\end{array}$ & $\begin{array}{l}\text { Excellent effluent quality in terms of } \\
\text { COD, BOD and nutrient removal is } \\
\text { achieved. }\end{array}$ & $\begin{array}{l}\text { Effluent quality in terms of COD is fair } \\
\text { but further treatment is required. } \\
\text { Nutrient removal is very poor. }\end{array}$ \\
\hline Energy & High energy is required. & $\begin{array}{l}\text { These processes produce energy in the } \\
\text { form of methane. }\end{array}$ \\
\hline Biomass yield & $\begin{array}{l}\text { In comparison to anaerobic process, } 6- \\
8 \text { times greater biomass is produced }\end{array}$ & Lower biomass is produced. \\
\hline Loading rate & $\begin{array}{l}\text { Maximum } 9000 \mathrm{~g} \quad \mathrm{COD} / \mathrm{m}^{3} \mathrm{~d} \text { is } \\
\text { reported in literature. }\end{array}$ & $\begin{array}{l}\text { Very high Loading rate of } 31 \mathrm{~kg} \\
\mathrm{COD} / \mathrm{m}^{3} \mathrm{~d} \text { has been reported. This is the } \\
\text { reason for smaller reactor volume and } \\
\text { lesser area. }\end{array}$ \\
\hline $\begin{array}{l}\text { Oil and grease } \\
\text { removal }\end{array}$ & $\begin{array}{l}\text { These do not cause serious problems } \\
\text { in aerobic processes (Komatsu et al., } \\
\text { 1991). }\end{array}$ & $\begin{array}{l}\text { Fats in wastewater shows the inhibitory } \\
\text { action during anaerobic treatment of } \\
\text { dairy wastewaters }\end{array}$ \\
\hline Shock loading & Excellent performance in this regard. & $\begin{array}{l}\text { Anaerobic processes showed not good } \\
\text { responses to this shock loading. }\end{array}$ \\
\hline $\begin{array}{l}\text { Alkalinity } \\
\text { addition }\end{array}$ & No need. & $\begin{array}{l}\text { There is need for alkalinity addition to } \\
\text { maintain the } \mathrm{pH} \text { because } \mathrm{pH} \text { changes } \\
\text { during the digestion of lactose. }\end{array}$ \\
\hline
\end{tabular}

Despite various studies and some advantages of the aerobic biological treatment of dairy wastewater (Table.3), there are a number of drawbacks associated with these studies. High energy requirement by aerobic treatment methods is the primary drawback of these processes. Dairy effluents have high COD and organic content and are warm, enabling them to be ideal for anaerobic treatment. Furthermore, no requirement for aeration, low amount of excess sludge production, and low area demand are additional advantages of anaerobic treatment processes in comparison to aerobic processes (Table 3).

Consequently, a number of studies have been reported in open literature for the treatment of dairy wastewater by anaerobic methods.

\section{LITERATURE REVIEW}

U. B. Deshannavar et. al.[4] [2012], have studied the upflow anaerobic fixed-bed reactor for digestion of dairy industry effluent using polypropylene pall rings as a packing media and found that average COD removal efficiency of $87 \%$ and maximum biogas production of $9.8 \mathrm{l} / \mathrm{d}$ was achieved.

T. Ramesh et al [13] [2012]has studied a Fixed Film and Fixed Bed Anaerobic Reactor for treating Dairy Waste Water and found that COD reduction is a maximum of $80.88 \%$ for a varying influent COD from 1500 to $4700 \mathrm{mg} / \mathrm{lit}$. for the OLR of $0.004 \mathrm{~kg} \mathrm{COD} / \mathrm{m}^{2} /$ day and HLR of $0.003 \mathrm{~m}^{3} / \mathrm{m}^{2}$.day. The maximum gas conversion ratio is $0.265 \mathrm{~m}^{3}$ of biogas per $\mathrm{kg}$ of COD removed.

Sathyamoorthy G.L et.al[11] [2012] have studied the performance of the anaerobic hybrid reactor (AHR) which is a combination of Upflow anaerobic sludge blanket reactor (UASBR) (suspended biomass) at bottom and Anaerobic Filter Reactor (AFR) (attached biomass) at top to treat dairy wastewater. He used the Bioflow ${ }^{\circledR} 30$ shape PolyPropylene (PP) inert media as the reactor filter media and revealed that the Anaerobic Hybrid Reactors (AHRs) were effective in the treatment of low-strength dairy wash-water giving 85\% COD removal for an OLR of about $4.2 \mathrm{~g} \mathrm{COD/L.d} \mathrm{and} \mathrm{HRT} \mathrm{of} 0.9 \mathrm{~d}$. in BOD, COD and VSS of dairy wastewater in batch and repeated batch cultivation systems. He found that the efficiency of COD removal is associated with the nature and properties of support material. Eventually, the maximum percentage removal of COD, BOD and 
VSS turned out to be as $96 \%, 93 \%$ and $90 \%$, respectively, with the application of $21 \mathrm{Kg} \mathrm{COD} / \mathrm{m}^{3} / \mathrm{d}$ loading in batch reactor filled with gravels.

Deshpande D.P. et. al. [8] [2012], have used the Upflow anaerobic packed bed bioreactor (UAPB) with an internal diameter of $20 \mathrm{~cm}$ and a height of $45 \mathrm{~cm}$ using seashell as a packing material for dairy wastewater treatment. He used the UAPB not only for treatment but he proved that with the help of UAPB dairy industry effluent is very good raw material for production of methane gas, commercially known as BIO-GAS, which can be use as a fuel and can replace the other fuel and COD value also decreases from $71526 \mathrm{mg} / \mathrm{lit}$ to $42200 \mathrm{mg} / \mathrm{lit}$ as the time increases from first day to the 56th day of the experiment.

J. I. Qazi et.al[6] [2011] has studied a number of biofilm support media including foam cubes, bamboo rings, fire bricks, $\mathrm{PVC}$ rings and gravels to immobilize biomass for reduction in $\mathrm{BOD}_{5}, \mathrm{COD}$ and VSS of dairy wastewater in batch and repeated batch cultivation system in Anaerobic Fixed Film Biotreatment. Eventually, he found that the maximum percentage removal of COD, BOD and VSS turned out to be as $96 \%, 93 \%$ and $90 \%$, respectively, with the application of $21 \mathrm{Kg} \mathrm{COD} / \mathrm{m}^{3} / \mathrm{d}$ loading in batch reactor filled with gravels.

Monali Gotmare et.al[9] [2011] has studied a UASB reactor treating dairy wastewater. And found that reactor achieved COD, BOD, TSS removal efficiency was observed $87.06 \%, 94.50 \%$, and $56.54 \%$ respectively. The average gas production and methane gas conversion at optimum conditions was observed to be 179.35 $\mathrm{m}^{3} /$ day and $125.55 \mathrm{~m}^{3} /$ day, respectively.

Rana Kabbout et.al[] [2011] has studied the physicochemical treatment of Sweet Whey the major pollutant in Dairy industry by coagulation-flocculation using Aluminum sulphate Al2(SO4)3 as a coagulant because it reduce the hardness and the load of phosphate in the wastewater and found that $33 \%$ of the chemical oxygen demand, $45 \%$ of the turbidity, $72 \%$ of suspended matter and $20 \%$ of total phosphorus gets reduced.

G. Srinivasan et.al[14] [2009] have carried out experiments on Anaerobic Diphasic Fixed Film Fixed Bed (FFFB) digester in the treatment of a synthetic dairy wastewater in order to reduce the COD of dairy waste water and for the production of biogas. They have reported maximum removal of COD as $70.40 \%$ at a flow rate of $0.006 \mathrm{~m}^{3} /$ day for an overall OLR of $1.265 \mathrm{Kg} \mathrm{COD} / \mathrm{m}^{3}$.day giving a maximum yield of bio-gas at 0.330 $\mathrm{m}^{3}$ of gas / $\mathrm{kg}$ COD removed

G. D. Najafpour, et.al[15] [2009] have used Upflow anaerobic packed bed bioreactor (UAPB) to treat Dairy Wastewater. The Plexiglas reactor column was packed with a seashell, and found that high COD and Lactose removals of 94.5 and $99 \%$ at HRT of 16 h having highest yield of methane production and the maximum biogas volumetric production.

G.D. Najafpour, et.al[16] [2008] have used Upflow Anaerobic Sludge-Fixed Film (UASFF) Bioreactor for the Treatment of Dairy Wastewater. UASFF bioreactor was developed with tubular flow behavior in order to shorten the start-up period of UASB reactor at low HRT. In this treatment; the column was randomly packed with seashell and at HRT $48 \mathrm{~h}$ and temperature $36^{\circ} \mathrm{C}$ found that, the COD removal rate and lactose conversion of 97.5 and 98 percent respectively.

A. Arumugam, et.al[6] [2008] have used a three phase fluidized-bed bioreactor (FBBR) for the aerobic treatment of dairy wastewater using culture of living cells immobilized on support particles of ceramic, Teflon, glass supports were studied and found that percentage reduction in COD for ceramic, Teflon and glass particles are $91 \%, 85 \%$ and $78 \%$, respectively.

P. Sankar Ganesh, et.al[17] [2007] have studied the dairy industry wash water treatment by UASB reactor and reveals that about $75-85 \%$ of COD was removed from dairy wash waters coming into the UASBs at COD concentrations of $1200-2000 \mathrm{mg} / \mathrm{L}$ at $6 \mathrm{~h} \mathrm{HRT}$. This means that the wash water exiting from the UASBs have COD in the range 180-500 mg/L. Such dilute effluents can be easily and quickly polished by short duration (1-2 h) aeration.

In this research I would like to use fixed film fixed bed reactor using coir as a support media to treat the dairy industry wastewater which would be at lowest cost and is beneficial to industries. Fixed bed reactors offer the advantage of high-load systems, requiring much less volume and space, and hence less investment as compared to conventional systems. Furthermore, these systems tend to operate more stable under transient conditions, like fluctuations of substrates and $\mathrm{pH}$. Such advantages are of interest to those industries which produce large amounts and/or highly concentrated wastewaters, notably the food, paper and pulp industries. ${ }^{[15]}$

\section{CONCLUSION}

Fixed film processes are more superior when compared to suspended processes in several aspects. Small reactor size, simple operation and high reliability make this process a cost-effective system for biological treatment. In fixed-film anaerobic reactors, large amount of biomass remains in the filter to secure solid retention despite a short hydraulic retention times. Biomass accumulation and retention in biomass systems are enhanced by attachment to a fixed medium.

The upflow anaerobic fixed-bed reactors have several advantages over aerobic and conventional anaerobic reactors such as rapid start-up with minimum operational problems; ability to withstand shock loading 
without significant decrease in digestion efficiency; ability to adapt intermittent feeding and rapidity of restart after lengthy shut down periods; and lower hydraulic retention times. ${ }^{[15]}$ One of the advantages is high biomass per reactor volume which permits higher organic loading rate, short liquid detention times and good performance stability.

Anaerobic fixed bed reactors (AFBRs) has been successfully and widely applied for the treatment of dairy industry wastewater due to its capacity for microorganism retention on the support and, therefore, the hydraulic retention time can be considerably reduced. In addition, AFBRs are easy to acclimatize and can overcome influent variations or shock loads without process failure. Moreover, the construction, operation and maintenance cost of the AFBRs are lower than those required for other high-rate reactors. These characteristics make the AFBR extremely useful for the treatment of high and medium strength wastewaters like dairy industry wastewater.

\section{REFERENCES}

[1] Jai prakash kushwaha, Vimal chandra srivastava, and Indra deo mall, “An Overview of Various Technologies for the Treatment of Dairy Wastewaters" Critical Reviews in Food Science and Nutrition, 51:442-452 (2011)

[2] Dr. A. S. Kolhe, S. R. Ingale, Dr. R. V. Bhole, "Effluent of Dairy Technology" Shodh, Samiksha aur Mulyankan (International Research Journal) - ISSN-0974-2832 Vol. II, Issue-5 (Nov.08-Jan.09)

[3] Oneț Cristian, "Characteristics of the untreated wastewater produced by food industry" Analele Universității din Oradea, Fascicula:Protecția Mediului, Vol. XV, 2010

[4] U. B. Deshannavar, Basavaraj. R. K and Nandini M. Naik, "High rate digestion of dairy industry effluent by upflow anaerobic fixed-bed reactor", Journal of Chemical and Pharmaceutical Research, 2012, 4(6):2895-2899

[5] A. Tawfika, M. Sobheyb, M. Badawya; "Treatment of a combined dairy and domestic wastewater in an up-flow anaerobic sludge blanket (UASB) reactor followed by activated sludge (AS system)" Desalination 227 (2008) 167177

[6] Javed Iqbal Qazi, Muhammad Nadeem, Shagufta S. Baig, Shahjahan Baig and Quratulain Syed, “Anaerobic Fixed Film Biotreatment of Dairy Wastewater" Middle-East Journal of Scientific Research 8 (3): 590-593, 2011, ISSN 1990-9233,@ IDOSI Publications, 2011

[7] Kusum Lata, Arun Kansal, Malini Balakrishnan, K V Rajeshwari and V V N Kishore Tata Energy Research Institute, Biogas Users Survey 1998/99 in Nepal, "Evaluation of Biomethanation Potential of Selected Industrial Organic Effluents in India"

[8] Deshpande D.P., Patil P.J. and Anekar S.V., "Biomethanation of Dairy Waste", Research Journal of Chemical Sciences, ISSN 2231-606X Vol. 2(4), 35-39, April (2012)

[9] Monali Gotmare, R.M.Dhoble, A.P.Pittule "Biomethanation of Dairy Waste Water Through UASB at Mesophilic Temperature Range" (IJAEST @ 2011, Vol.8 Issue 1, 001-009

[10] Rana Kabbout, Moemen Baroudi, Fouad Dabboussi, Jalal Halwani, Samir Taha, "Characterization, Physicochemical and Biological Treatment of Sweet Whey (Major Pollutant in Dairy Effluent), 2011 International Conference on Biology, Environment and Chemistry IPCBEE vol.2 (2011) (C) (2011)IACSIT Press, Singapoore

[11] Sathyamoorthy G.L. and Saseetharan M.K., "Dairy Wastewater Treatment by Anaerobic Hybrid Reactor - a study on the Reactor Performance and Optimum Percentage of Inert Media Fill inside Reactor" Vol.16 (1) March (2012) Res. J. Chem. Environ

[12] A. Arumugam and P. L. Sabarethinam, "performance of a three-phase fluidized bed reactor with different support particles in treatment of dairy wastewater" ARPN Journal of Engineering and Applied Sciences VOL. 3, NO. 5, October 2008, ISSN 1819-6608

[13] T.Ramesh, V.Nehru kumar, G .Srinivasan, "Kinetic Evaluation of Fixed Film Fixed Bed Anaerobic Reactor by Using Dairy WasteWater" International Journal of Pharmaceutical \& Biological Archives 2012; 3(4):835-837

[14] G. Srinivasan, R. Subramaniam and V. Nehru kumar; "A Study on Dairy Wastewater Using Fixed-Film Fixed Bed Anaerobic Diphasic Digester" ; American-Eurasian Journal of Scientific Research 4 (2): 89-92, 2009

[15] G. D. Najafpour, M. Tajallipour, M. Komeili, and M. Mohammadi, "Kinetic model for an up-flow anaerobic packed bed bioreactor: Dairy wastewater treatment” African Journal of Biotechnology Vol. 8 (15), pp. 3590-3596, 4 August, 2009

[16] G.D. Najafpour, B.A. Hashemiyeh, M. Asadi and M.B. Ghasemi, "Biological Treatment of Dairy Wastewater in an Upflow Anaerobic Sludge-Fixed Film Bioreactor” American-Eurasian J. Agric. \& Environ. Sci., 4 (2): 251-257, 2008

[17] P. Sankar Ganesh, E. V. Ramasamy, S. Gajalakshmi, R. Sanjeevi and S. A. Abbasi, "Studies on treatment of lowstrength effluents by UASB reactor and its application to dairy industry wash waters"; Indian Journal of Biotechnology, Vol 6, April 2007, pp 234-238 